\title{
Characterization of a Bacteriocin from Bacillus amyloliquefaciens
}

\author{
Susan Brock, Judith Knadler, Tabitha Ritter and Jason C. Baker* \\ Missouri Western State University, St. Joseph, Missouri, USA \\ *Corresponding author
}

\begin{abstract}
A B S T R A C T
Keywords

Bacteriocin, antimicrobial peptide, Bacillus amyloliquefaciens, antibacterial, antifungal

Article Info

Accepted: 17 May 2018 Available Online: 10 June 2018

A potentially novel bacteriocin, currently named Bacocin, was discovered from a strain of Bacillus amyloliquefaciens. Bacocinsupernatant had a broad antibacterial spectrum, inhibiting Gram-positive and Gram-negative bacteria such as Escherichia coli, Staphylococcus and Salmonella species, and Listeria monocytogenes, but not against Enterococcusor Bacillus species. It significantly inhibited fungal growth of species such as Aspergillus, Stachybotrys, and Botrytis but not Rhizopus or Fusarium. It was stable at $121^{\circ} \mathrm{C}$ for $30 \mathrm{~min}$ and at $100^{\circ} \mathrm{C}$ for more than 1 hour. It maintained inhibitory activity through freeze/thaw and extreme $\mathrm{pH}$ conditions. Bacocin's activity was not significantly destroyed by Proteinase K or Trypsin but was by high levels of Pronase E.Bacocin was purified from cell-free supernatant by ammonium sulfate precipitation, hydrophobic chromatography, and membrane size filtration. The stability and inhibitory spectrum of Bacocin makes it a good candidate for biological control of potential human, animal, and plant pathogens.
\end{abstract}

\section{Introduction}

Since the 1940s, reports of antimicrobial substances abound in the scientific literature. These include early discovery of substances such as Nisin (Mattick and Hirsch, 1947) and Subtilin (Salle and Jann, 1945), now classified as bacteriocins. Bacteriocins aremicrobicidal or microbistaticpeptides produced by a wide range of bacterial speciesand have a wide variety of characteristics including a range of molecular masses, heat stability, and posttranslational modifications. Perhaps the most widely studied group of bacteriocins come from the lactic acid bacteria (LAB) (AlvarezSieiro et al., 2016; Nes et al., 2007; Zendo, 2013) followed closely by studies on bacteriocins from Bacillus species (Tagg et al., 1976; Abriouel et al., 2011). LAB bacteriocins have been classified and reclassified over the years (Alvarez-Sieiro et al., 2016; Nes et al., 2007)to include three classes and sometimes subclasses; lantibiotics (class I), small, linear peptides (class II), and large heat-labile (class III). More recently, a classification system with classes and subclasses paralleling LAB bacteriocins has been proposed for the Bacillus bacteriocins (Abriouel et al., 2011). This includes posttranslationally modified peptides (class I), non-modified peptides (class II), and other linear peptides (class III). Bacteriocins have been isolated from more than 20 Bacillus species, including several strains for some 
species, and from environments as diverse as fish intestines, fermented soybeans, dairy products, and soil. Some have a known broad inhibitory spectrum against both bacteria and fungi (He et al., 2006) while others have been more narrowly tested and shown to inhibit only a few bacterial species (Cherif et al., 2008). They vary in molecular mass from over $200 \mathrm{kDa}$ for some of the Megacins (Brusilow and Nelson, 1981)to less than $1.5 \mathrm{kDa}$ for Lichenin (Pattnaik et al., 2001), with most smaller than $10 \mathrm{kDa}$.

The potential application of bacteriocinsare plentiful and include food preservation for both humans and livestock (Abee et al., 1995; Riley and Wertz, 2002; Halimi et al., 2010; Bali et al., 2016)and crop plant health (Yoshida et al., 2001; Arguelles-Arias et al., 2009; Chen et al., 2009; Lee et al., 2009; Wu et al., 2015). Bacillus species producing bacteriocins may have the greatest application potential due to the diverse environments in which they live and their stability as endospores. This makes the use of purified bacteriocins as well as vegetative cells or spores possible for diverse applications. Some bacteriocins produced by Bacillus amyloliquefaciens have been recently reported. A southern Brazil isolate has shown inhibitory activity against some Gram-positive and Gram-negative species, but not yeast, and is moderately heat stable (Lisboa et al., 2006). Another, bacteriocin RX7, was also broadly effective against bacteria as well as against Candida albicans, more stable at $121^{\circ} \mathrm{C}$, and less susceptible to various proteases (Lim et al., 2016). Additionally, genome analysis of $B$. amyloliquefaciens GA1 has revealed several known and potential bacteriocins (ArguellesArias et al., 2009) including Amylolysin (Arguelles Arias et al., 2013) but properties have not been evaluated. This current work reports the evaluation of a newly discovered bacteriocin produced by Bacillus amyloliquefaciens, currently named Bacocin, which has a combined broader temperature range stability, extreme $\mathrm{pH}$ stability, protease resistance, and broader inhibitory spectrum when compared to other Bacillus-produced bacteriocins.

\section{Materials and Methods}

\section{Bacterial isolation and identification}

Moistened sterile cotton swabs were used for random sampling of surfaces (floor, door knobs, tables, and water fountains) in a classroom and laboratory building at Missouri Western State University. Swabs were rubbed on nutrient agar plates and plates allowed to grow at $37^{\circ} \mathrm{C}$ for 48 hours. Biochemical analysis of colonies of interest was performed by automated Vitek system (bioMérieux, use courtesy of BoehringerIngelheim, St. Joseph, MO). 16s ribosomal RNA gene sequencing was conducted by Iowa State University Biotechnology Service DNA Facility. Cultures of interest were maintained frozen in $10 \%$ dextrose at $-80^{\circ} \mathrm{C}$.

\section{Bacocin production}

One $\mathrm{ml}$ Bacillus amyloliquefaciens from a $80^{\circ} \mathrm{C}$ stock culture was inoculated into 100 mls of nutrient broth and placed on a rotary shaking incubator at $150 \mathrm{rpm}$ and $30^{\circ} \mathrm{C}$. After 22-24 hours of incubation, the entire $100 \mathrm{mls}$ of culture was transferred into $900 \mathrm{mls}$ of fresh nutrient broth in a $2 \mathrm{~L}$ Erlenmeyer flask and shaken at $150 \mathrm{rpm}$ and $30^{\circ} \mathrm{C}$. Cells and supernatant were harvested by centrifugation at $10,000 \mathrm{xg}$ for $30 \mathrm{~min}$ after 72 to 96 hours growth. The bacteriocincrude supernatant was filtered thru a $0.2 \mu \mathrm{m}$ Nalgene filter and stored at $4^{\circ} \mathrm{C}$.

\section{Bacocin purification}

$50 \mathrm{ml}$ Bacillus amyloliquefaciens cell-free crude supernatant was brought slowly to $45 \%$ 
ammonium sulfate saturation at room temp and stirred overnight. The suspension was centrifuged at $10,000 \mathrm{xg}$ for 30 minutes and the pellet was collected into $2 \mathrm{ml}$ sterile phosphate-buffered saline or ultra-pure water. $0.5 \mathrm{ml}$ of re-suspended pellet was added to a $0.5 \mathrm{ml}$ C8 hydrophobic chromatography column (Fisher PrepSepextraction column) and washed with $20 \mathrm{ml}$ sterile water. Bacocin was purified and released from the column by consecutive washings with $2 \mathrm{ml}$ each of $10 \%$, $20 \%$, and $50 \%$ ethanol. Ethanol was evaporated from these fractions by Centrivap evaporating/concentrating system and sterile deionized water added to bring fractions back to volume. Finally, samples showing antimicrobial activity were spun in a Centricon 10 (Millipore) and the flow-through collected to remove contaminating proteins greater than $10 \mathrm{kDa}$.

\section{Bacocin Activity Assay}

Anti-bacterial activity was determined by spectrophotometric cell density growth assay in a 96-well plate (Falcon 351172) (Cabo et al., 1999). $100 \mu \mathrm{l}$ challenge organism (see Table 1) at $10^{4} \mathrm{CFU} / \mathrm{ml}$ (unless otherwise noted) in fresh nutrient broth was added to a well with $100 \mu \mathrm{l}$ Bacocin (either crude supernatant, PBS diluted crude supernatant, or purified) or sterile phosphate-buffered saline (PBS) (positive growth control). By this method, all wells contained equal concentration of fresh growth media. Plates were incubated for $20-24 \mathrm{hrs}$ at $37^{\circ} \mathrm{C}$ and read on a microtiter plate reader at $600 \mathrm{~nm}$ to evaluate cell density. Assays were performed in quadruplicate, at a minimum, for each experimental condition and each experiment was performed at least twice.

Anti-fungal activity was determined by spreading $50 \mu \mathrm{l}$ of fungal hypha and spore suspension, in duplicate, at the density of a 0.5 McFarland Standard on Sabouraud dextrose
(SAB-DEX) plates with or without Bacocincontainingcrude supernatant present at $40 \%$ by volume. Plates were incubated 3 to 8 days, depending on fungal species, and evaluated visually each day for percent area of plate covered by growth compared to control plates.

Sensitivity of antimicrobial activity to proteases, heat, and $\mathrm{pH}$

Bacocin-containing crude supernatant was treated at $37^{\circ} \mathrm{C}$ with Proteinase $\mathrm{K}$, Trypsin, or Pronase E (Sigma-Aldrich) at indicated final concentrations and times. Each protease was inactivated at $100^{\circ} \mathrm{C}$ for $30 \mathrm{~min}$. To evaluate thermal stability, samples of Bacocincrude supernatant were held at $-80,-20,22$, and $37^{\circ} \mathrm{C}$ for 10 days as well as temperatures from 50 to $100^{\circ} \mathrm{C}$ for $60 \mathrm{~min}$. Additionally, samples were autoclaved at $121^{\circ} \mathrm{C}$ for $30 \mathrm{~min}$ and boiled for up to $6 \mathrm{hrs}$. All samples were brought back to room temperature for use in the activity assay. To determine $\mathrm{pH}$ stability, samples were titrated to the indicated $\mathrm{pH}$ using $1 \mathrm{M} \mathrm{HCl}$ or $\mathrm{NaOH}$, allowed to sit for 2 hours at room temperature, then titrated back to neutral immediately prior to assay. In all cases, remaining inhibitory activity was tested against Staphylococcus epidermidis (ATCC12228).

\section{Results and Discussion}

\section{Identification of the bacteriocin-producing species}

One bacterial colony with lobate morphology isolated from floor swabs of Agenstein Hall, Missouri Western State University, was observed to have a small $(\sim 2 \mathrm{~mm})$ zone of clearing on Tryptic Soy Agar in which no other floor isolates would invade. 16s ribosomal RNA gene sequencing provided a 99\% identity with several Bacillus species, including B. amyloliquefaciens. To identify at species level, this colony was grown in pure 
culture in nutrient broth, Gram stained to find the expected Gram-positive streptobacilli, and subjected to automated biochemical analysis by Vitek system. Analysis provided a $99 \%$ confidence identity as Bacillus amyloliquefaciens (data not shown).

\section{Bacocin production and assay optimization}

To determine the maximal Bacocin production under our growing conditions, the B.amyloliquefaciens culture was grown as described and samples taken every 24 hours for 4 days. A minimum of 48 hours culture growth is needed for cells to produce strong antimicrobial activity against Staphylococcus epidermidis (Fig. 1). 72 and 96 hour growth supernatant typically showed equal potency (seen also in Fig. 2). Additionally, each sample was tested against varying concentration of $S$. epidermidis in the inhibition assay to establish a testable ratio of Bacocin supernatant to challenge organism. The supernatant of $B$. amyloliquefaciens culture grown for only 48 hours was less effective at inhibiting $S$. epidermidis growth at initial cell concentrations above $10^{5}$ cells $/ \mathrm{ml}$ (Fig. 2). Bacocin supernatant from both 72 and 96 hour cultures were equally effective in this study against $S$. epidermidis at $2.2 \times 10^{6}$ cells/ml or less. Almost no inhibitory effects were seen when $S$. epidermidis was at $2.2 \mathrm{X}$ $10^{7}$ cells/ml or higher starting concentration in the assay. From these data we established that our assays would contain $1 \times 10^{3}$ cells in each $200 \mu \mathrm{l}$ assay (or $5 \times 10^{3}$ cells $/ \mathrm{ml}$ )giving us strong control culture growth during the assay period while avoiding swamping Bacocin inhibitory effects due to culture density. We also performed 2-foldserial dilutions of a typical preparation of 96 hour $B$. amyloliquefaciens growth supernatant in PBS and found we could dilute samples 4-fold and maintain full efficacy against $S$. epidermidis at $5 \times 10^{3}$ cells $/ \mathrm{ml}$. Samples diluted 8 -fold or more quickly lost inhibitory activity (Fig. 3).

\section{Antimicrobial spectrum}

Bacocin-containing cell-free supernatant was tested against a variety of Gram-positive and Gram-negative bacterial species as well as several fungal species (Table 1). As an antibacterial agent, Bacocin was highly effective at inhibiting the growth of several Staphylococcus species as well as Listeria monocytogenes, Salmonella species, and Shigellasonnei. It was moderately effective at inhibiting Escherichia coli and Lactococcuslactis but only minimally effective against Enterococcus faecalis and Pseudomonas aeruginosa. Bacocin caused no inhibition of the growth of vegetative cells of the related Bacillus cereus strain we tested. When tested against fungi, Bacocin fully inhibited the growth of Aspergillus niger, Stachybotryschartarum, and a Botrytis species but was only moderately effective against a Penicillium species and not effective at all against Rhizopusoligosporus or a Fusarium species. Interestingly, we observed $90 \%$ control plate coverage for the Penicillium species after 24 hours but only 5\% coverage on the Bacocin-containing plates. At day 3 the Penicillium species fully covered the control plate and visual inspection revealed heavy fruiting body and spore production. At day 3 the Penicillium species grown on Bacocincontaining plates increased coverage to $60 \%$ of the plate area but fruiting bodies and spores were not present, only vegetative hyphae (data not shown). Taken together, these data demonstrate the broad range of inhibitory activity of Bacocin against several bacterial and fungal species, including manyspecies which can be pathogenic to humans, animals, and crop plants.

\section{Stability of Bacocin in pH and temperature}

Table 2 shows the effects $\mathrm{pH}$ and temperature hadon the inhibitory action of Bacocincontaining supernatant. 
Table.1 Antimicrobial spectrum of crude Bacocin supernatant

Indicator organism

Gram-positive

Staphylococcus epidermidis (ATCC12228)

Staphylococcus aureus (ATCC25923)

Staphylococcus warneri (clinical isolate)

Staphylococcus capitis (clinical isolate)

Enterococcus faecalis (ATCC19433)

Lactococcus lactis (ATCC11454)

Bacillus cereus (ATCC11778)

Listeria monocytogenes (ATCC43251)

Gram-negative

Escherichia coli (ATCC25922)

Salmonella enteritidis (ATCC13076)

Salmonella species (clinical isolate)

Shigella sonnei (ATCC25931)

Pseudomonas aeruginosa (ATCC27853)

Fungi

Aspergillus niger (ATCC16404)

Penicillium chrysogenum (ATCC48907)

Rhizopus oligosporus (environmental isolate)

Fusarium species (ATCC48112)

Stachybotrys chartarum (environmental isolate)

Botrytis species (environmental isolate)
$\%$ growth inhibition

97.9

97.5

97.2

99.7

13.3

59.2

0

90.9

66.3

98.8

71.7

71.5

24.1

100
40
0
0
100
100

Table.2 Effects of $\mathrm{pH}$ and temperature on Bacocin antimicrobial activity

Crude Bacocin supernatant treatment

\begin{tabular}{|l|}
\hline None (control) \\
\hline pH \\
\hline 2 \\
\hline 4 \\
\hline 6 \\
\hline 8 \\
\hline 10 \\
\hline 12 \\
\hline
\end{tabular}

temperature

$-80^{\circ} \mathrm{C}(10$ days $)$

$-20^{\circ} \mathrm{C}(10$ days $)$

$22^{\circ} \mathrm{C}(10$ days $)$

$37^{\circ} \mathrm{C}$ (10 days)

$50^{\circ} \mathrm{C}(60 \mathrm{~min})$

$70^{\circ} \mathrm{C}(60 \mathrm{~min})$

$90^{\circ} \mathrm{C}(60 \mathrm{~min})$

$100^{\circ} \mathrm{C}(60 \mathrm{~min})$

$121^{\circ} \mathrm{C}(30 \mathrm{~min})$
$\%$ growth inhibition of S. epidermidis 97.9

97.7

98.1

97.7

98.1

98.1

98.1

95.9

97.2

98.3

98.6

97.9

97.6

97.6

97.4

94.9 
Fig.1 Culture growth time and the antibacterial activity of crude supernatant. Bacillus amyloliquefaciens was cultured in nutrient broth and supernatant harvested at the indicated times. Staphylococcus epidermidis growth was measured without (open bars) and with (shaded bars) Bacocin-containing crude supernatant. Values represent the average \pm standard deviation of eight replicates for each condition

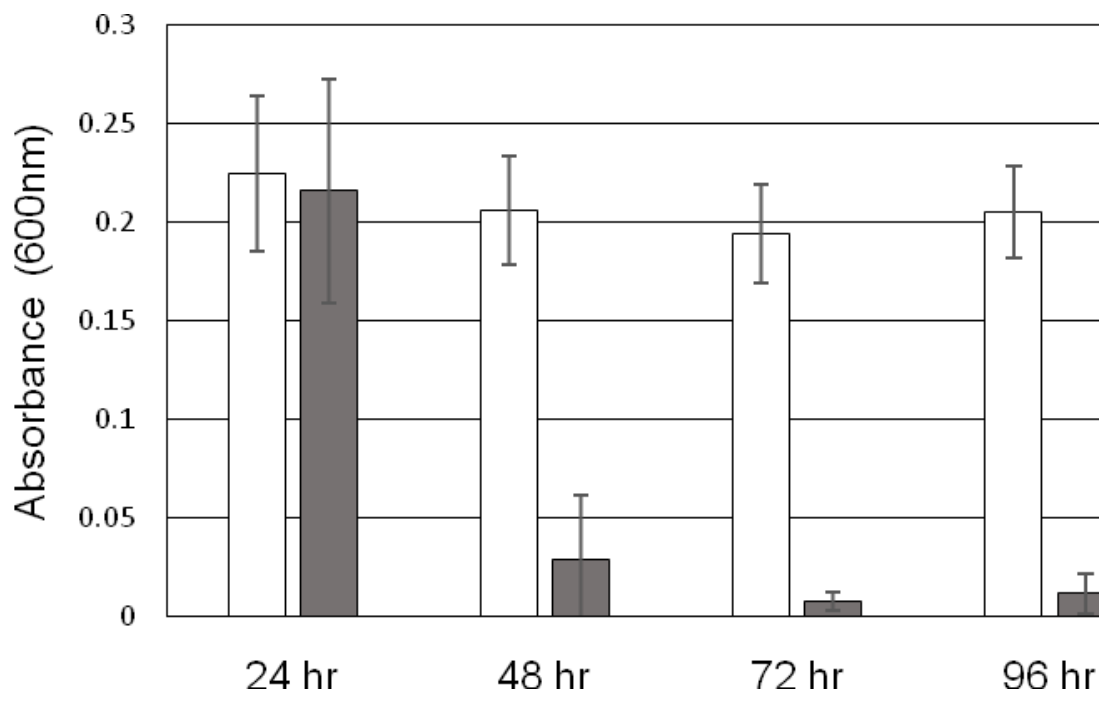

Fig.2 Inhibitory ability of Bacocin-containing supernatants against increasing concentrations of Staphylococcus epidermidis. Concentration of S. epidermidis in the initial assay set-up is listed on the X-axis. Bacocin-containing Bacillus amyloliquefaciens cell-free supernatant was harvested at the indicated times. Values represent the average of eight replicates for each condition

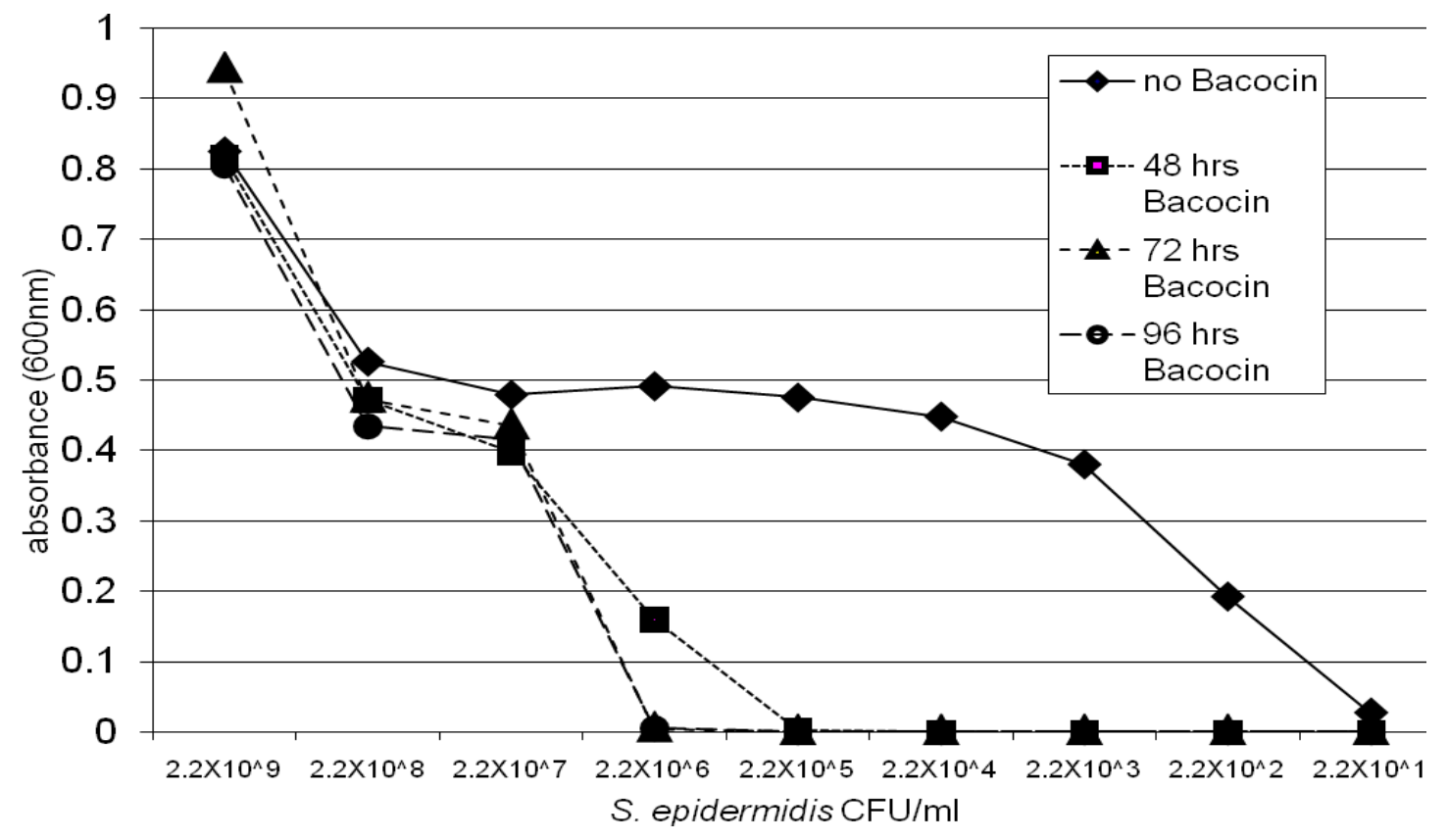


Fig.3 Effects of dilution of Bacocin-containing supernatant on inhibitory activity. Two-fold serial dilutions of Bacocin supernatant from 96 hour culture growth were prepared to challenge the growth of Staphylococcus epidermidis at $5 \times 10^{3}$ cells $/ \mathrm{ml}$. Values represent the average of

eight replicates for each condition

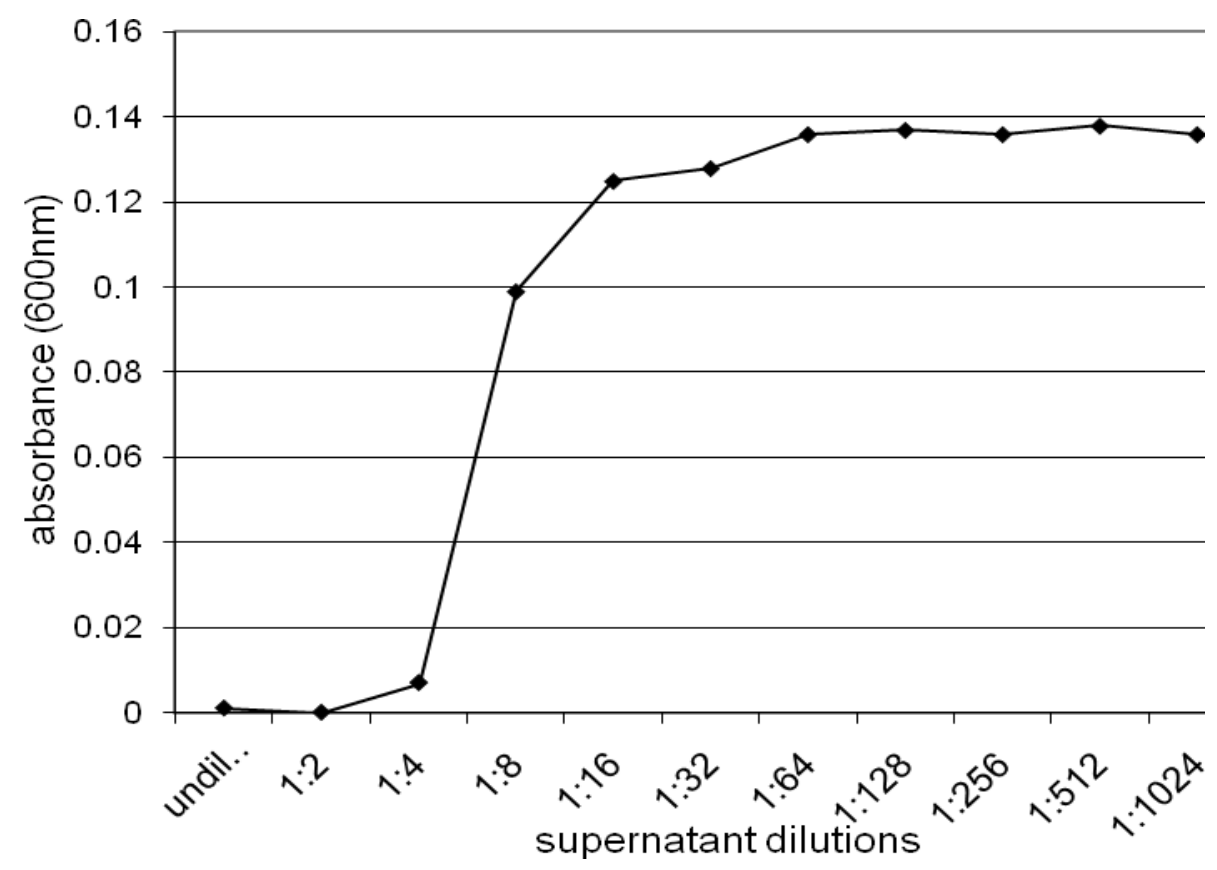

Fig.4 Effect of heat on Bacocin-containing supernatant inhibitory activity. Bacocin was heated to $100^{\circ} \mathrm{C}$ for the indicated times, cooled to room temperature, and used to challenge the liquid culture growth of Staphylococcus epidermidis. Values represent the average \pm standard deviation of four replicates for each condition

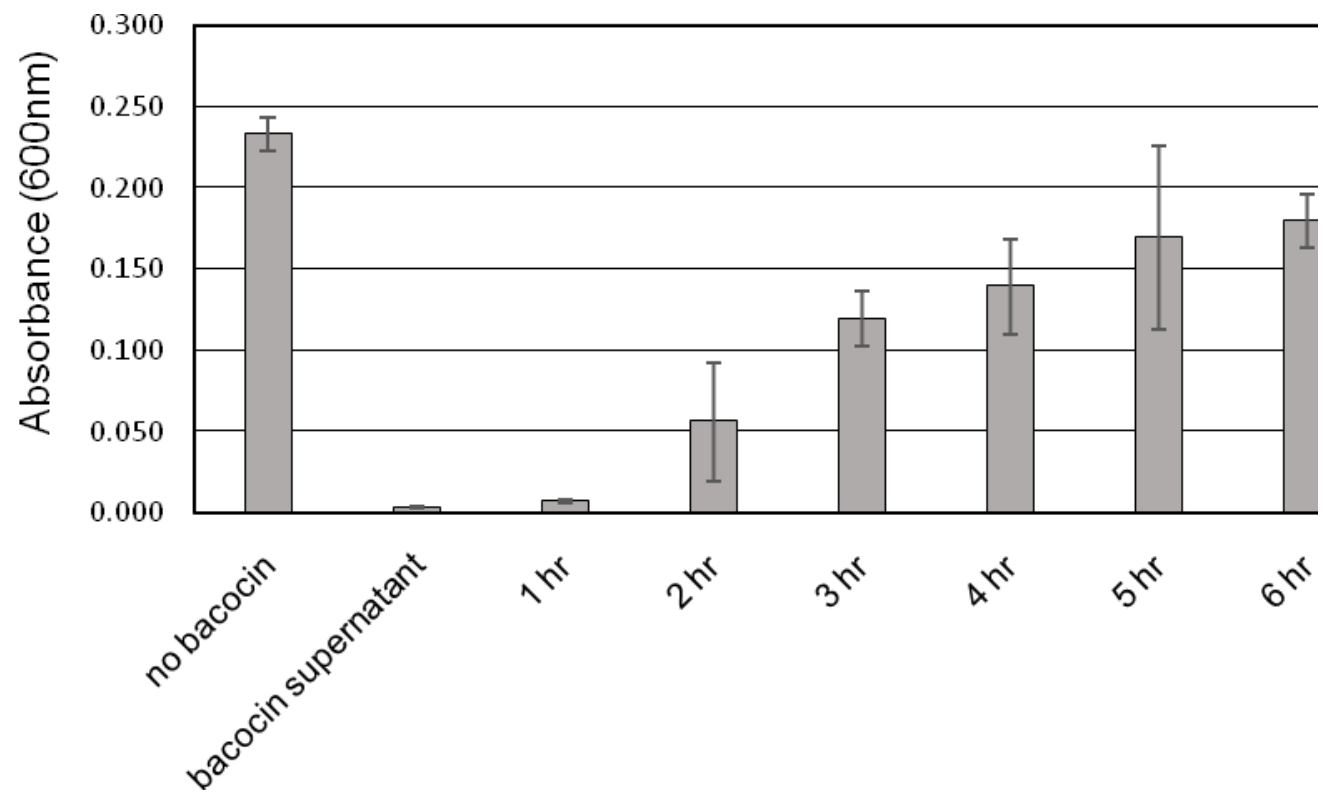


Fig.5 Loss of antimicrobial activity due to pronase E treatment. Bacocin-containing supernatant was treated with pronase $\mathrm{E}$ at the protease concentrations and times indicated. Following protease inactivation, the treated Bacocin was use to challenge the growth of Staphylococcus epidermidis. S. epidermidis growth is reported relative to control lacking Bacocin-containing supernatant. Values represent the average \pm standard deviation of four replicates for each condition

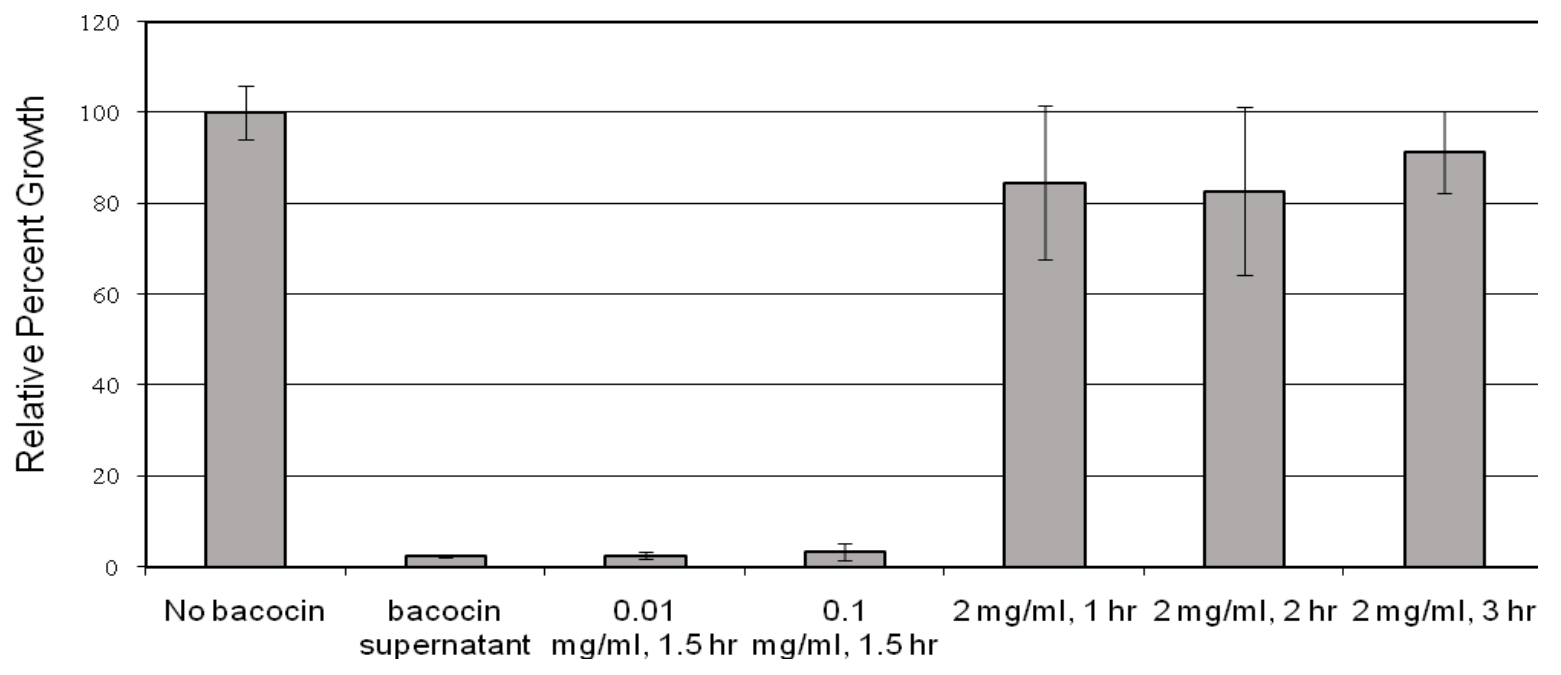

Fig.6 SDS-PAGE and Blue Silver staining of purified Bacocin. Lane 1: molecular weight marker; lane 2: partially purified fraction containing inhibitory activity following ammonium sulfate and hydrophobic column purification steps; lane 3: empty; lane 4: Centricon 10 concentrated, filtered flow-through sample containing inhibitory activity. The small arrow indicates the putative purified Bacocin

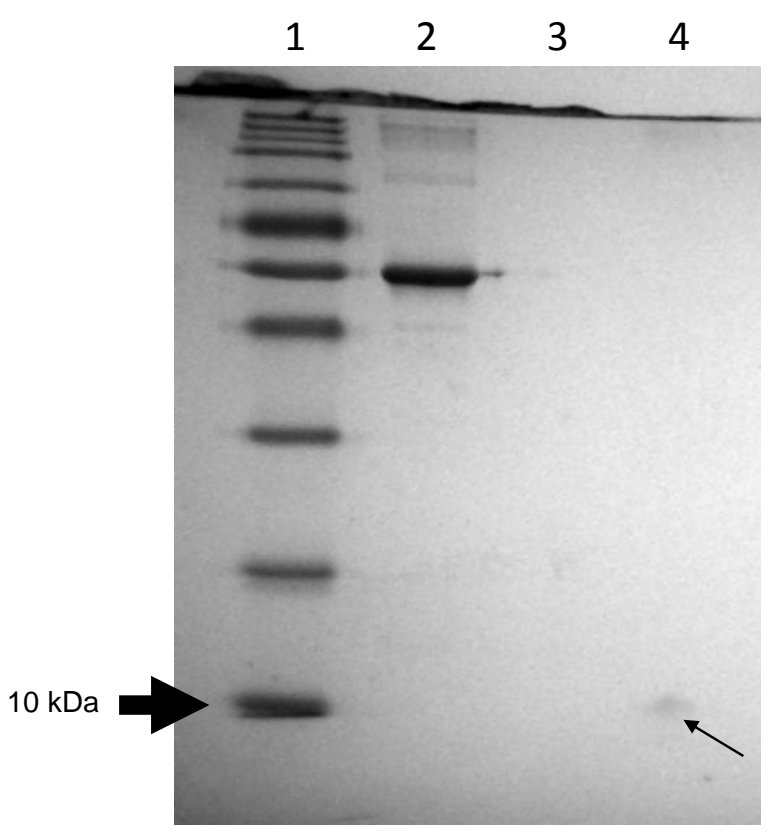


In all cases $S$. epidermidis was used as the challenge organism. $\mathrm{pH}$ values from 2 to 12 were tested and Bacocin retained its inhibitory ability through all $\mathrm{pH}$ extremes. Inhibitory activity was nearly fully retained after freezing Bacocinsupernatant at $-80^{\circ} \mathrm{C}$ or $-20^{\circ} \mathrm{C}$ for 10 days as well as storage for 10 days at $22^{\circ} \mathrm{C}$ and $37^{\circ} \mathrm{C}$. Temperatures up to $100^{\circ} \mathrm{C}$ for 60 minutes did not destroy the inhibitory effect nor did autoclaving $\left(121^{\circ} \mathrm{C}\right)$ for 30 minutes. At $100^{\circ} \mathrm{C}$, a dose-dependent curve can be seen with progressively decreasing inhibitory effects observed from 2 to 6 hours of heating (Fig. 4). Interestingly, more that $20 \%$ inhibition of $S$. epidermidiswas still retained even after 6 hours heating of Bacocinsupernatant at $100^{\circ} \mathrm{C}$.

\section{Bacocin susceptibility to protease degradation}

Bacocin's antimicrobial activity against $S$. epidermidis was not reduced by treatment with proteinase $\mathrm{K}$ ( $1 \mathrm{mg} / \mathrm{ml}$ for 3 hours $)$. Trypsin treatment at $2 \mathrm{mg} / \mathrm{ml}$ for 2 hours had no effect although a $13.5 \%$ reduction in inhibition was apparent after 3 hours exposure to trypsin (data not shown). However, treatment of Bacocin by pronase $\mathrm{E}$ at $2 \mathrm{mg} / \mathrm{ml}$ for 1 hour eliminated an average of $84 \%$ of its antimicrobial ability and 3 hours treatment eliminated 91\% (Fig. 5).

\section{Bacocin purification}

Bacocin was purified from $B$. amyloliquefaciens crude supernatant through a three-step protein purification process consisting of ammonium sulfate precipitation, hydrophobic chromatography, and membrane-based size filtration (as described in materials and methods). Inhibitory activity against $S$. epidermidis was followed for all fractions at each purification step (data not shown) and the final product, which demonstrated $100 \%$ inhibitory activity, was visualized on $15 \%$ SDS-PAGE stained by Blue Silver staining method (Candiano et al., 2004). The single purified band obtained from this process was found with a molecular size of just under $10 \mathrm{kDa}$ (Fig. 6). This estimate was based on both SDS-PAGE migration relative to standards as well as the protein having passed through the 10,000 molecular weight cut-off membrane of the Centricon 10 used in purification.

We have isolated a Bacillus amyloliquefaciens strain, as identified by $16 \mathrm{~s}$ rRNA gene sequencing and biochemical testing, which produces a secreted antimicrobial activity. Because initial platebased zone of inhibition observations with both live culture and crude Bacocincontaining supernatant showed very small and inconsistent clearing zones, we pursued and developed a liquid culture-based spectrophotometric assay. Many bacteriocins are not readily diffusible in agar-based tests (Cabo et al., 1999) and this was the case for Bacocin. Inhibitory effects are easily missed in well-based diffusion or disk diffusion assays. By using a cell growth density-based assay we were also able to quantify inhibitory effects in more detail. The percent inhibition could then be calculated by dividing the blank-subtracted cell density at $600 \mathrm{~nm}$ for the Bacocin-containing samples by the value for the corresponding control sample and subtracting from one (Cabo et al., 1999). While this method works well to quantify inhibition of bacterial growth, filamentous fungi (i.e. molds) are not easily quantified by this method. Because of this, we decided to rely on Bacocin present throughout the agar growth media rather than diffusion from a well for fungal inhibition studies. This meant our observations were less quantitative than our spectrophotometric assay and relied on visual estimation of the percent of the plate covered by the fungus as well as the thallus 
density as compared to control plates. For all tested species but the Penicillium species, this observation was completely obvious with either full growth or no growth present on the Bacocin-containing plates.

Cell growth density observations, the presence of endospores as detected by endosporestaining (data not shown), and the optimal Bacocin levels found at 72-96 hours of growth at $30^{\circ} \mathrm{Call}$ indicate Bacocin ispredominately produced in the stationary growth phase. This indicates Bacocin may play a role in protecting this species under stress conditions and when resources are limited in its environment. Some preliminary efforts to increase our Bacocin concentration in B. amyloliquefaciens crude supernatant by changing media composition and temperatures have been only minimally successful so production optimization remains an area for future studies. From our inhibitory spectrum evaluation using Bacocin crude supernatant, we found that Bacocininhibited multiple species of Gram-positive and Gramnegative bacteria, as well as several fungi. This suggests a mode of action against features common to diverse microbial groups (i.e. cell membrane composition). Further efforts will be pursued to understand the mode of action of Bacocin.

Bacocin was susceptible to pronase $\mathrm{E}$, was able to be precipitated by ammonium sulfate, and detectable by protein staining of an SDSPAGE gel, suggesting it is proteinaceous and therefore a bacteriocin or bacteriocin-like substance. Bacocin is highly stable after treatment at extreme $\mathrm{pH}$ and temperatures. This corresponds with bacteriocins isolated from several other Bacillus species (CladeraOlivera et al., 2004; Lim et al., 2016; Lisboa et al., 2006) and may indicate minimal secondary structure beyond loops created by disulfide bonds. In our assay approach, it was necessary to titrate Bacocin samples back to neutral following two hours of $\mathrm{pH}$ extremes in order to avoid $\mathrm{pH}$ killing effects of the challenge organism in our liquid-based assay. Other agar-based zone of inhibition methods rely only on media-based buffering and dilution to eliminate false-positive inhibitory effects. Similarly, all heat or cold treated samples were allowed to return to room temperature prior to assay. It is possible extreme $\mathrm{pH}$ and temperature alters the structure and potential effects of Bacocin but this alteration is not permanent, allowing Bacocin to remain antimicrobial after being returned to neutral $\mathrm{pH}$ and room temperature.

To date, efforts to determine the sequence of Bacocin have been unsuccessful. Multiple attempts at $\mathrm{N}$-terminal protein sequencing of the purified peptide have provided minimal and inconsistent data. Structurally, many heatstable, small bacteriocins contain unusual amino acids, side chain substitutions, or are cyclic and contain no free amino termini (Abriouel et al., 2011; Gabrielsen et al., 2014). We also see evidence that Bacocin is produced in low concentration under our conditions, as demonstrated by loss of inhibition if supernatant is diluted more than 4 fold and a lack of any visible bands until the supernatant was concentrated in the final step of our purification process, even under staining conditions designed to detect $\sim 5 \mathrm{ng}$ of protein. We suspect our ability to sequence Bacocin is being hindered by one or more those these issues. We also suspect Bacocin has a hydrophobic nature due to the usefulness of hydrophobic chromatography in its purification. Many bacteriocins from Bacillus species have not been definitively sequenced if they come from strains whose genomes are not currently available (Banerjee et al., 2017; Kindoli et al., 2012; Lisboa et al., 2006).Because of its reported inhibitory spectrum and stability, unique from other Bacillus bacteriocins reported in the literature, Bacocin represents a potentially novel 
bacteriocin with possible use in inhibiting human, animal, and plant pathogens.

\section{Acknowledgments}

We wish to thank the Missouri Western State University PORTAL program for funding, Boehringer Ingelheim, St. Joseph, Missouri for access to the Vitek bacterial identification system, Dr. Kristen Walton for review and editing of this manuscript, and Travis Brown and Meredith Triplet for experiment assistance.

\section{References}

Abee, T., Krockel, L. and Hill, C. (1995) Bacteriocins: modes of action and potentials in food preservation and control of food poisoning. Int. J. Food Microbiol. 28, 169-185.

Abriouel, H., Franz, C.M.A.P., Ben Omar, N. and Galvez, A. (2011) Diversity and applications of Bacillus bacteriocins. FEMS Microbiol. Rev. 35, 201-232.

Alvarez-Sieiro, P., Montalban-Lopez, M., Mu, D. and Kuipers, O.P. (2016) Bacteriocins of lactic acid bacteria: extending the family. Appl. Microbiol. Biotechnol. 100, 2939-2951.

Arguelles Arias, A., Ongena, M., Devreese, B., Terrak, M., Joris, B. and Fickers, P. (2013) Characterization of amylolysin, a novel lantibiotic from Bacillus amyloliquefaciens GA1. PloS One 8, e83037.

Arguelles-Arias, A., Ongena, M., Halimi, B., Lara, Y., Brans, A., Joris, B. and Fickers, P. (2009) Bacillus amyloliquefaciens GA1 as a source of potent antibiotics and other secondary metabolites for biocontrol of plant pathogens. Microb. Cell Factories 8, 63.

Bali, V., Panesar, P.S., Bera, M.B. and Kennedy, J.F. (2016) Bacteriocins: Recent Trends and Potential Applications. Crit. Rev. Food Sci. Nutr. 56, 817-834.
Banerjee, G., Nandi, A. and Ray, A.K. (2017) Assessment of hemolytic activity, enzyme production and bacteriocin characterization of Bacillus subtilis LR1 isolated from the gastrointestinal tract of fish. Arch. Microbiol.199, 115-124.

Brusilow, W.S. and Nelson, D.L. (1981) Improved purification and some properties of megacinCx, a bacteriocin produced by Bacillus megaterium. J. Biol. Chem.256, 159-164.

Cabo, M.L., Murado, M.A., Gonzalez, M.P. and Pastoriza, L. (1999) A method for bacteriocin quantification. J. Appl. Microbiol. 87, 907-914.

Candiano, G., Bruschi, M., Musante, L., Santucci, L., Ghiggeri, G.M., Carnemolla, B., Orecchia, P., Zardi, L. and Righetti, P.G. (2004) Blue silver: a very sensitive colloidal Coomassie G-250 staining for proteome analysis. Electrophoresis 25, 1327-1333.

Chen, X.H., Scholz, R., Borriss, M., Junge, H., Mogel, G., Kunz, S. and Borriss, R. (2009) Difficidin and bacilysin produced by plant-associated Bacillus amyloliquefaciens are efficient in controlling fire blight disease. $\mathrm{J}$ Biotechnol. 140, 38-44.

Cherif, A., Rezgui, W., Raddadi, N., Daffonchio, D. and Boudabous, A. (2008) Characterization and partial purification of entomocin 110, a newly identified bacteriocin from Bacillus thuringiensis subsp. Entomocidus HD110. Microbiol. Res. 163, 684-692.

Cladera-Olivera, F., Caron, G.R. and Brandelli, A. (2004) Bacteriocin-like substance production by Bacillus licheniformis strain P40. Lett. Appl. Microbiol. 38, 251-256.

Gabrielsen, C., Brede, D.A., Nes, I.F. and Diep, D.B. (2014) Circular bacteriocins: biosynthesis and mode of action. Appl. Environ. Microbiol. 80, 6854-6862.

Halimi, B., Dortu, C., Arguelles-Arias, A., Thonart, P., Joris, B. and Fickers, P. (2010) Antilisterial Activity on Poultry Meat of Amylolysin, a Bacteriocin from 
Bacillus amyloliquefaciens GA1. Probiotics Antimicrob. Proteins 2, 120 125.

He, L., Chen, W. and Liu, Y. (2006) Production and partial characterization of bacteriocin-like pepitdes by Bacillus licheniformis ZJU12. Microbiol. Res. 161, 321-326.

Kindoli, S., Lee, H.A. and Kim, J.H. (2012) Properties of Bac W42, a bacteriocin produced by Bacillus subtilis W42 isolated from Cheonggukjang. J. Microbiol. Biotechnol. 22, 1092-1100.

Lee, K.D., Gray, E.J., Mabood, F., et al., (2009) The class IIdbacteriocin thuricin-17 increases plant growth. Planta 229, 747755.

Lim, K.B., Balolong, M.P., Kim, S.H., Oh, J.K., Lee, J.Y. and Kang, D.-K. (2016) Isolation and Characterization of a Broad Spectrum Bacteriocin from Bacillus amyloliquefaciens RX7. BioMed Res. Int. 2016, 8521476.

Lisboa, M.P., Bonatto, D., Bizani, D., Henriques, J.A.P. and Brandelli, A. (2006) Characterization of a bacteriocinlike substance produced by Bacillus amyloliquefaciens isolated from the Brazilian Atlantic forest. Int. Microbiol. Off. J. Span. Soc. Microbiol. 9, 111-118.

Mattick, A.T.R. and Hirsch, A. (1947) Further observations on an inhibitory substance (nisin) from lactic streptococci. Lancet Lond. Engl. 2, 5-8.

Nes, I.F., Yoon, S., Diep, D.B. and others (2007) Ribosomallysynthesiszed antimicrobial peptides (bacteriocins) in lactic acid bacteria: a review. Food Sci. Biotechnol. 16, 675.

Pattnaik, P., Kaushik, J.K., Grover, S. and Batish, V.K. (2001) Purification and characterization of a bacteriocin-like compound (Lichenin) produced anaerobically by Bacillus licheniformis isolated from water buffalo. J. Appl. Microbiol. 91, 636-645.

Riley, M.A. and Wertz, J.E. (2002) Bacteriocins: evolution, ecology, and application. Annu. Rev. Microbiol. 56, 117-137.

Salle, A.J. and Jann, G.J. (1945) Subtilin, an antibiotic produced by Bacillus subtilis; action on various organisms. Proc. Soc. Exp. Biol. Med. Soc. Exp. Biol. Med. N. Y. N 60, 60-64.

Tagg, J.R., Dajani, A.S. and Wannamaker, L.W. (1976) Bacteriocins of gram-positive bacteria. Bacteriol. Rev. 40, 722-756.

Wu, L., Wu, H., Chen, L., Yu, X., Borriss, R. and Gao, X. (2015) Difficidin and bacilysin from Bacillus amyloliquefaciens FZB42 have antibacterial activity against Xanthomonasoryzae rice pathogens. Sci. Rep. 5, 12975.

Yoshida, S., Hiradate, S., Tsukamoto, T., Hatakeda, K. and Shirata, A. (2001) Antimicrobial Activity of Culture Filtrate of Bacillus amyloliquefaciens RC-2 Isolated from Mulberry Leaves. Phytopathology 91, 181-187.

Zendo, T. (2013) Screening and characterization of novel bacteriocins from lactic acid bacteria. Biosci. Biotechnol. Biochem. 77, 893-899.

\section{How to cite this article:}

Susan Brock, Judith Knadler, Tabitha Ritter and Jason C. Baker. 2018. Characterization of a Bacteriocin from Bacillus amyloliquefaciens. Int.J.Curr.Microbiol.App.Sci. 7(06): 1492-1503. doi: https://doi.org/10.20546/ijcmas.2018.706.177 